\title{
TEACHING VOCABULARY THROUGH SNAKE AND LADDER BOARD GAME IN THE TENTH GRADE OF SMA MUHAMMADIYAH 1 MALANG
}

\author{
Dita Fitriana, Rahmawati Khadijah Maro \\ Universitas Muhammadiyah Malang \\ E-mail: ditafitriana13@gmail.com
}

\begin{abstract}
Vocabulary is the language resource, students have to know vocabularies to produce sentences. Thus, the aim of this study was to find out whether snake and ladder board game could improve students' vocabulary mastery or not. The subject analyzed in this research were the tenth grade students of SMA Muhammadiyah I. The experimental group was X-IPSI while the control group was X-IPS-II.

This study employed quantitative research design. This design was selected due to this present study was required a concrete evidence whether Snake and Ladder Board Game could enhance students' vocabulary mastery in senior high school or not. In this study the instruments used were pre-test, treatment, and post-test. The pre-test was given to both experimental and control group. After the pre-test was given to both groups, then the experimental group was treated or taught by using snake and ladder board game, while the control group was not treated by using snake and ladder board game. After that, the post-test was also given to both experimental and control group. The researcher used t-test to know the significant difference between the mean score of the experimental and control group. The process of t-test was counted using computer SPSS 17 version.

The result of this study was shown that snake and ladder board game could improve students' vocabulary mastery due to the score of pre-test in control group was higher than the pre-test score of experimental group. Otherwise, the post-test score of experimental group was higher than the control group. Accordingly, related to the result of this experimental research, the researcher concludes that snake and ladder board game can improve students' vocabulary mastery in the first year students of senior high school.
\end{abstract}

Keywords: Snake and Ladder Board Game, Teaching, Vocabulary

\section{INTRODUCTION}

Vocabulary is one of the language components playing a key role in all language skills: listening, speaking, reading and writing. Based on the theory, it can be inferred that learning vocabulary is important and it is the key to learner's understanding what they hear and read for the sake of good communication to other people. Afterward, as noted by Fardhini (as cited in Kamali, 2014), vocabulary is one of the language components playing a key role in all language skills: listening, speaking, reading and writing. Based on this theory, it is very important for the 
students to learn vocabularies of the target language since vocabulary itself is the pillar of a language. However, teaching vocabulary also is not easy, especially in senior high school, it is quiet complicated because the students have inadequate vocabulary.

In this case, the teachers were challenged because they have to develop their teaching methods or media in order to attract students' attention and motivation in learning English. One of the media that may the teacher use to transfer the material is by using a game. A game use is a solution offered to learn vocabulary because game helped students to remember more words (Tunchalearnpanih, 2012). Considering this reason, teaching English using game might help the students to improve their ability in learning English especially their vocabularies.

Kamali (2014) elucidates that Snake and Ladder Board game is one of board games that can be used as an interesting medium and increase student's interest and motivation. Moreover, Hinebaugh (2009:2) states that board games are excellent tools for teaching fundamental and core educational skills. The previous statements strengthens the argument that games especially Snake and Ladder Board game could potentially support and very helpful in teaching and learning activities to improve students' vocabularies ability and also attract students' motivation in learning English. In line with the previous statements, in this present study the researcher focuses on teaching vocabulary in $10^{\text {th }}$ of SMA 1 Muhammadiyah Malang through Snake and Ladder Board gameThe researcher conducted an experimental research to examine the effectiveness of teaching vocabulary using an innovative game.

The result of this study is expected to give, first, theoretically for the next researchers and the readers, the output of this research might be useful as an 
additional information and knowledge for the next researchers. Moreover, the readers and further researchers could use this paper to beautify their vocabulary mastery. Secondly, practically for the teacher and the Students is to have a beneficial useful for teacher to help finding an appropriate method used in teaching vocabulary in order to accustomed the students to vocabulary mastery.

In this study, the researcher only focus on teaching vocabulary through Snake and Ladder Board game. Yet, the limitation of this research is $10^{\text {th }}$ grade of SMA Muhammadiyah 1 Malang. In order to avoid some misunderstanding about a certain word in this study, the researcher provides some explanation about certain terms as below:

\section{Games in Teaching Vocabulary}

Most educators believe that game gives a lot of positive influence in psychological development, intelligence, and skill aspect. In a game, the aspects of the competition, speed and skill also should be achieved at once. Learning through playing game can help the students in reducing their stress and develop their sense of humor.

Through a game, students are practice in making decisions and socializing with others so that the students will be active in the teaching and learning process. Starting a teaching and learning process with a game also has good function to supports students' success in learning activity.

\section{Snake and Ladder Board Game}

Snake and Ladder Board game is one of interesting games that can be used in teaching vocabulary. Snake and ladder Board game not only enjoyable game, but also facilities the students to learn about counting, life interaction and socialization. In this game, implicitly the senior high school students can learn about up and down 
in life or about joys and troubles Based on that reason the researcher decided to develop the snake and ladder board game so that it can be used as a media to build and reinforce student's vocabulary mastery at first grade senior high school as well as develop their ability to socialize with their friends by playing and working together in a team or group

A board game for snake and ladder game is with squares measuring $10 \times 10$ (Nachiappan et al., 2014:220). Squares on the board are counted starting with the number 1 , which is from the bottom left corner up to number 10 in the lower right corner, from right to left starting number 11 on the second lineuntil number 20 and so on until the number 100 in the upper left corner. The parcels have pictures with a message and deed. Order or good deed will usually via a ladder to reach the higher box while bad deeds will recoil into the lower compartment through the snake. Hence, the next part is the detail information about the procedure of using snake and ladder board game to teach vocabulary.

\section{METHOD}

This design is selected due to this present study requires a concrete evidence whether Snake and Ladder Board Game can enhance students' vocabulary mastery in senior high school or not A "population" consists of all the subjects you want to study (Yount, 2006:71). While sampling is a portion of a population (Ary et al. 2010:148). This research equipped cluster sampling because this is referred to the unit chosen that is not an individual but, rather, a group of the last sampling is systematic, this sampling differs from simple random sampling in that the various choices are not independent. Among those mentioned sampling technique, the population of this study is the all of the first year students of SMA Muhammadiyah 1 Malang while the samples are taken from two different classes, those are X-1 
(experimental group) and -2 (control group). In this case, those classes will be treated in different treatment in order to investigate the effectiveness of those two ways of teaching. This population and samples are selected because students at senior high school grade especially in the first year are ordinarily less capable in mastering English vocabulary. The instrument in this study is used to collect the data. In this study the instruments used are pre-test, treatment, and post-test. Those will be elaborated as follows. Using t-test to know the difference significantly between the means of experimental and control group. The process of t-test is counted using computer SPSS 17 version.

\section{FINDINGS AND DISCUSSION}

\section{The Mean Scores of Pre-Test of Experimental and Control Group}

The pre-test was given to both experimental and control group before the researcher applied the treatment. Then, the result of the pre-test was counted using SPSS 17. Below are the results of the pre-test in both experimental and control group.

Table 4.1.1.1 The Result of Pre-test of Experimental and Control Group

\begin{tabular}{|l|c|c|}
\hline Statistic Descriptive & $\begin{array}{c}\text { X-IPS I } \\
\text { (Experimental }\end{array}$ & $\begin{array}{c}\text { X-IPS II } \\
\text { (Control } \\
\text { Group) }\end{array}$ \\
\hline $\mathrm{N}$ & 20 & Group) \\
\hline Means & 47 & 73 \\
\hline Standard Deviation & 9,23 & 7,32 \\
\hline Minimum & 30 & 60 \\
\hline Maximum & 60 & 90 \\
\hline
\end{tabular}




\begin{tabular}{|l|r|rr|}
\hline Variabel & F & Sig. \\
& & & \\
\hline Pre-test & 1,393 & & 0,245 \\
& & & \\
\hline
\end{tabular}

Based on the above table, it can be seen that the data from those two classes were the same, which were 20 . In the above table shows that the mean score of $\mathrm{X}$ IPS-II class was higher than the mean of X-IPS I class, in which it was 73 and 47. Thus, it can be concluded that the pre-test score in X-IPS-II was higher than the pretest score of X-IPS-I.

Table 4.1.1.2 The Result of Post-test of Experimental and Control Group

\begin{tabular}{|l|c|c|}
\hline Statistic Descriptive & $\begin{array}{c}\text { X-IPS I } \\
\text { (Experimental }\end{array}$ & $\begin{array}{c}\text { X-IPS II } \\
\text { (Control }\end{array}$ \\
& Group) & 20 \\
\hline $\mathrm{N}$ & 22 & 81,5 \\
\hline Means & 91,8182 & 11,367 \\
\hline Standard Deviation & 12,203 & 50 \\
\hline Minimum & & 90 \\
\hline Maximum & 50 & \\
\hline
\end{tabular}

The above tables show that the total data between X-IPS-1 and X-IPS-2 were different; X-IPS-1 was 22 while X-IPS-II was 20. The mean score of X-IPS-I was higher than the mean score of X-IPS-II, in which it was 91, 8182 for X-IPS-I and 81, 5 for X-IPS-II. Thus, it can be concluded that the post-test score in X-IPS-I was higher than the post-test score of X-IPS-II.

\section{Independent Sample T-test}


The samples were X-IPS-I and X-IPS-II. Before the T-test was conducted, the equality test variant (homogeneity) should be done as the requirement of conducting T-test.

\section{Pre-test Data}

\section{Homogeneity Testing}

In testing the homogeneity, the hypothesis used was the variant which comes from two classes that were the same (homogeneity) and the alternative hypothesis was the variants which come from two classes that were not the same. This data can be concluded homogeny if the score of Sig. was more than 0,05 .

\section{Levene's Test for Equality of Variances}

\begin{tabular}{|l|c|c|}
\hline Variabel & F & Sig. \\
\hline Pre-test & 1,393 & 0,245 \\
\hline
\end{tabular}

Based on table above it can be seen that the value of sig was 0,245 . This score was higher than 0.05 . Thus, it can be concluded that the variant data was homogeneous and can be proceed to the independent t-test.

\section{T-test for the Equality of Means}

The hypotheses are as below:

Ho: There was no difference between the mean score of the pre-test in X-IPS-I and X-IPS-II

$\mathrm{H}_{\mathrm{a}}$ : There was a difference between the means score of the pre-test in X-IPS-I and X-IPS-II

If the score of sig. was less than 0.05 , then there was a difference in both the mean score of pre-test. The Sig. score was attached in the table below:

\section{T-test for Equality of Means}




\begin{tabular}{|l|c|c|}
\hline Variabel & T & Sig. \\
\hline Pre-test & $-9,864$ & 0,000 \\
\hline
\end{tabular}

Based on the above table, it shows that the Sig. score was lower than 0,05. It means that there was a difference in the mean score of the X-IPS-I and X-IPS-II.

\section{Post-test Data}

\section{Homogeneity Test}

In testing the homogeneity, the hypothesis used was the variant which comes from two classes that were the same (homogeneity) and the alternative hypothesis was the variants which come from two classes that were not the same. This data can be concluded homogeny if the score of Sig. was more than 0,05 .

\section{Levene's Test for Equality of Variances}

\begin{tabular}{|l|c|c|}
\hline Variabel & F & Sig. \\
\hline Post-test & 0,150 & 0,701 \\
\hline
\end{tabular}

Related to the above table, it can be seen that the score of sig was 0.701 . This score was higher than 0.05 . Thus, it can be concluded that the variant data was homogeneous and can be proceed to the independent T-test.

\section{T-test for the Equality of Means}

The hypotheses are as below.

$\mathrm{H}_{0}$ : There was no difference between the mean score of the pre-test in X-IPS-I and

\section{X-IPS-II}

$\mathrm{H}_{\mathrm{a}}$ : There was a difference between the means score of the pre-test in X-IPS-I and XIPS-II 
If the score of Sig. was less than 0.05 , then there was a difference in both pre-test mean score. Thus, the Sig. score was attached in the table below:

\section{T-test for The Equality of Means}

\begin{tabular}{|l|c|c|}
\hline Variabel & T & Sig. \\
\hline Post-test & $-3,278$ & 0,002 \\
\hline
\end{tabular}

In line with the above table, it shows that the score of Sig. was less than 0,005 in which it means that there was a difference towards the post-test score of X-IPS-I and X-IPS-II.

In accordance with the above data, it can be concluded that $\mathrm{H}_{0}$ was rejected and $\mathrm{H}_{\mathrm{a}}$ was accepted. This means that there was a difference between the mean of pre-test and post-test of both experimental and control group. The mean score of X-IPS-1 was 91,8182 while X-IPS-2 was 81,5 . It means that the mean score of X-IPS-I was higher than the X-IPS-II. Thus, based on the independent sample test above, it can be concluded that teaching vocabulary through snake and ladder board game could improve students' vocabulary mastery.

\subsection{Discussion}

In accordance with the previous analysis above, the researcher found that teaching vocabulary through snake and ladder board game could improve students' vocabulary mastery in the first grade of senior high school. It was proven by the significant differences toward the average scores of the pre-test and post-test in both experimental and control group. The mean score of pre-test of experimental group was 47 while the control group was 73 . Otherwise, the score of post-test of experimental group was increase up to 91,8182 and 11,367 for the control group. In this case, it can be seen that the experimental group which is X-IPS-I was gained a higher score than the control group after its class was being treated by using snake 
and ladder board game. It means that there was a significant change towards the vocabulary mastery of the tenth grade of senior high school after the implementation of snake and ladder board game.

The findings of this research were also in line with the explanation of Astri (2016:37), snake and ladder board game can be beneficial for language learning in which they are normally designed in accordance with real life activities. This game offers the students with an opportunity to exercise real and meaningful language context while interacting in the game with others involved. For instance: the students were asked to answer the question card which were they gained from the board of snake and ladder game, then they have to answer the question inside the question card which consists of Indonesian vocabulary and they have to answer it by mentioning what was the English version of that vocabulary. In this case, they researcher takes "things around school" as the theme in order to give them the real things which exist around them to be taught, then after answering the question, the students should make a sentence related to the vocabulary they had been translated. In this case the students learn to put the vocabulary in the precise sentence in order to make a meaningful sentence related to the vocabulary itself. Thus, in this game the students have an opportunity to explore their knowledge to the real life and also express their knowledge which were they gained from the teacher in the previous meeting to answer the question card. In this game the students also could interact with others if they found the difficulty to answer the question. Another supporting research was conducted by Wright et al. (2006:4), to minimize the difficulty it is essential that the learners be familiar with the game in their own language. That is why in this research the researcher teaches snake and ladder board game with "things around school" as 
the theme in order to make the students exploring things around them with their own language.

In accordance with the above explanations, it can be concluded that games were highly motivate the students to learn the subject because the games itself were amusing, interesting and also give more opportunity to the students to express and explore their feelings with their own language. As noted by Halimah (2012:114), games are often much opportunity for the learner to practice and repeat the sentence patterns and vocabulary. This means that teaching by using games could help the teachers to transfer the knowledge to the students easier and create an active environment through the game. In this case, snake and ladder board game was an example of game which can be used to teach English especially vocabulary because this game was served in colorful pictures in which it will attract the students' interest. Accordingly, related to the result of this experimental research, the researcher concludes that snake and ladder board game can improve students' vocabulary mastery in the first year students of senior high school.

\section{CONCLUSION}

The experimental group in this research was X-IPS-1 while the control group was X-IPS-2. Based on the calculation by using independent sample T-test, the Sig. score was less than 0,05 in which it can be concluded that $\mathrm{H} 0$ (null hypothesis) was rejected and $\mathrm{Ha}($ alternativehypothesis)was accepted.

In conclusion, the hypothesis stated that the students who were taught by using snake and ladder board game reaped better skill in mastering English vocabulary than those who were not taught by using snake and ladder board game. Accordingly, in accordance with the above explanation, it can be concluded that snake and ladder board game could improve students' vocabulary mastery. 


\section{REFERENCES}

Ary, Donald et al. 2010. Introduction to Research in Education ( $8^{\text {th }}$ Edition). Belmont: Wadsworth.

Astri, Devi. 2016. The Effectiveness of Using Snakes and Ladders Game Technique to Improve Students' Simple Past Tense Ability At Tenth Grade Of SMA Islam Batu. Unpublished Undergraduate Thesis. University of Muhammadiyah Malang.

Ball, Deborah Loewenberg and Francesca M. Forzani1. 2009. The Work of Teaching and the Challenge for Teacher Education. Journal of Teacher Education, 60(5) $497-511$.

Crystal,David. 2003. English as a Global Langguage (2nd Ed.). USA: Cambridge University Press.

Halimah. 2012. Implementing Language Games "Snake and Ladders" to Improve Students' Speaking Ability. Undergraduate Thesis Program University of Sebelas Maret.

Kamali, Lailiyah. 2014. The Effect of Using a Snake and Ladder Game on the Eighth Grade Students' Vocabulary Achievement at SMPN 1 Jenggawah in the 2012/2013 AcademicYear. Jember: UNJ.

Nachiappan, Suppiah et al. 2014. Snake and Ladder Games in Cognition Development on Students with Learning Difficulties. Review of Arts and Humanities. Vol. 3, No. 2, pp. 217-229.

Richard, J.C, and Renandya, W.A.2002. Methodologhy in Language learning: A Case Study in the National University of Laos, International Journal of English Language Education, Vol. 1, No. 1.

Talak, K.A. 2010. Using Games In A Foreign Language Classroom. IPP Collection. Paper484. (online), (http://digitalcollections.sit.edu/ipp_collection/484), accessed on November 252011.

Tunchalearnpanih, Pisut. 2012. Using Games on P.6 Students' Vocabulary Learning. Thailand: Srinakharinwirot University (SWU).

Wright, A., Betteridge, D., \& Buckby, M. 2006. Games for Language Learning. Cambridge: Cambridge University Press.

Yount, Rick. 2006. Research Design and Statistical Analysis for Christian Ministry ( $4^{\text {th }}$ Edition). 